\title{
The Unknown Factors: Evidence from the Cave Monasteries and the Significance of Georgian Vernacular Religion as a Relic of Earlier Ritual Practices
}

\author{
The Areas of Research yet to be Fully Explored: A Brief Explanation \\ of the Purpose of This Chapter
}

Any research question as complex as trying to unravel the level of cultural interaction between Syria and Georgia in late antiquity is bound to have many facets to it, particularly when the problem is approached in an interdisciplinary manner. Although the previous chapters have largely revealed the same pattern of evidence, with the archaeological, art historical, liturgical and historical data seeming generally to point in the same direction, there are two outstanding issues that have not been resolved and, in both cases, it seems that future research is necessary.

The first of these issues is the question of cave monasticism. It will be remembered that the only definitively Syrian early Christian artefact excavated thus far in Kartli or Kakheti was the Symeon Stylites medallion discovered at Davit Gareja in Kakheti. ${ }^{1}$ For this reason alone it would seem sensible to look at the relationship between this complex and Syria, but as will be outlined below, there are a number of other reasons why it is desirable to undertake a comparative study of cave monasticism across the wider region. Secondly there is the tantalising echo of the Syrian bema liturgy in the use of pre-altar crosses in the Georgian highlands (and previously elsewhere as well) as well as the use of the tau-shaped drosha offering a possibility of interplay between early Christian rituals and vernacular beliefs. ${ }^{2}$ Accordingly this chapter will offer some context to these two outstanding questions and discuss why these topics appear fruitful areas of future research in the hope of stimulating more interest and debate.

\footnotetext{
1 See Chapter 3 .

2 See Chapter 6.

(C) EMMA LOOSLEY LEEMING, 2018 | DOI:10.1163/9789004375314_010
} 


\section{Cave Dwelling as a Sub-branch of Monasticism}

One element that frequently recurs in eastern and oriental monasticism is the practice of using caves as monastic cells. We know that the link between cavedwelling and ascetic practices pre-dates Christianity as evidence from groups such as the Essenes makes clear, but how it became an integral part of eastern monastic practices is perhaps rather opaque. We find this phenomenon wherever the physical geography accommodates it across the Levant, down into Egypt and up into Asia Minor and the Caucasus. Whilst this form of monasticism is widely known and there have been various studies of the practice, thus far this research has concentrated on regional surveys or looked within the territories of a modern nation state rather than trying to take a wider view and place these practices within a wider framework encompassing the eastern and oriental Christian world of late antiquity. These studies have also concentrated on issues of monastic practice and organisation or, where decoration remains-most notably in Cappadocia in contemporary Turkey—approached the material from an art historical standpoint rather than seeking to contextualise the monuments from a more interdisciplinary standpoint.

Because of this relative lack of research these cave monasteries have generally been characterised as eremitic or cenobitic and the evolution of the lavra model has been traced, but beyond this there has yet to be a concerted effort to ascertain whether or not this cave monasticism was broadly similar across the wider eastern Mediterranean and Caucasus or whether it existed in variant forms specific to different locations in the eastern Mediterranean, Asia Minor and the Caucasus. As mentioned above what follows will not answer these questions, but is rather intended as a first step in highlighting the issues with a view to stimulating further research in this area. ${ }^{3}$

The primary reason for this interest in the context of the current research is because although there is relatively little evidence of Syrian influence in the architecture of conventional churches in Kartli and Kakheti, at first glance it seems that there there is the possibility of some parallels between the cave monasteries of eastern Georgia, the ancient Iberia, and the cave monasteries of Lebanon which was classified as part of greater Syria in late antiquity. In contemporary Syria we have only one true cave monastery in the sense that the monks lived in caves, even though they worshipped in a conventional stone-built church built on a promontory in the midst of their cave-hermitages

3 In fact this subject is envisaged as the subject of a future research project by the author. 
rather than having a rock-cut chapel. ${ }^{4}$ Several other monastic foundations have incorporated elements of rock-cut architecture even if they are not true cave monasteries perse, so there is an awareness of the relationship between ascetic monasticism and cave-dwelling even if it is not common and is only found in the region abutting the contemporary Lebanese border. Since, as mentioned above, the only religious artefact definitively linked to Syria yet found in Georgia was also discovered in a cave at Davit Gareja this gives us a small amount of circumstantial evidence for a link between the two traditions and therefore this is another reason for considering whether an exploration of cave monasticism may help us understand the exact relationship between these two cultures in late antiquity.

What follows is a speculative consideration of some of the material that points out the possible links between the two traditions and offers suggestions for future academic study. In no way is it intended to offer a definitive view of the situation, but rather it is a preliminary step in beginning to examine this possible relationship and is included in this work to offer as complete a view as currently feasible of the relationship between the two societies in late antiquity - even if this element of the question has taken second place to the archaeology and art history of conventional stone-built churches throughout the majority of this work.

\section{An Overview of the Location of Rock-Cut Monasteries in Greater Syria}

Naturally cave monasteries or rock-cut churches of all kinds depend upon the geological conditions of any given location; therefore in the modern country of Syria (as opposed to the ancient definition of that territory) there is only one region that is suitable for this kind of monument. ${ }^{5}$ The area in question is the Qalamoun, which encompasses the foothills of the Anti-Lebanon mountain range and comprises a number of largely Christian villages or Muslim villages

4 This is Deir Mar Musa al-Habashi near Nebek in the Qalamoun region of western Syria, see below for more information about this foundation.

5 Theoretically there could have been cave monasteries in the Limestone Massif of northwest Syria but the evidence of the Afrin valley and its environs suggests that, although some caves were inhabited in prehistory, in the Roman and early Christian eras caves, both natural and manmade, acted largely as funerary monuments or cisterns. There is, thus far, no evidence of caves used for monastic purposes in this area-unless for storage or mortuary purposes. 
with a significant Christian minority up until the present day. ${ }^{6}$ In the south west of this area are the well-known towns and Christian pilgrimage sites of Saydnaya and Maaloula, with their shrines to the Virgin and St. Thecla respectively. Both towns have monasteries and convents incorporating some element of the local rock, although neither are conventional rock-cut foundations in the same way as we encounter them elsewhere.

Here the cave above the monastery of Mar Thecla in Maaloula acts as a shrine, but is not absorbed into the day-to-day buildings of the convent below. Elsewhere in Maaloula there is an acknowledgement of the significance of the early Christian rock burials in the narrow gorge above the town, but they are not an active part of contemporary worship. Further south in Saydnaya, several churches have been adapted from earlier buildings and some are found in close proximity to caves-perhaps most notably at the Cherubim monastery high above the main town, but again the caves are not an intrinsic part of the Christian landscape except for Dayr Mar Elias in the nearby town of Ma'arat Saydnaya that was constructed over a cave and has a chapel with medieval frescoes still extant.

Therefore it is only Deir Mar Musa al-Habashi near Nebek ${ }^{7}$ where we find a typical lavra arrangement with the original inhabitants of the monastery living in the caves around a central chapel, refectory and library complex built on an east-facing spur of the limestone mountains. A manuscript in the British Museum confirms that by the late seventh century ${ }^{8}$ there was a monastic community at the site large enough to support an active scriptorium or at least to have had some form of monastic library. Archaeological survey suggests that the site was most probably originally a Roman fort over looking the limes in the valley below which was adapted for monastic usage in late antiquity. The church conforms to the norms of a standard late antique basilica although it was substantially altered, most notably by raising the height of the roof and adding rooms above the north and south aisles, in the Middle Ages. How-

6 This was the situation before the Syrian Civil War. Naturally the situation may have been altered by the population movements triggered by the war.

7 The Arabic word for monastery is usually transliterated into English as Dayr but in the case of this monastery the French and Italian variant Deir is used. This is because the foundation is now well known due to the social, interfaith and ecumenial work of the Community and many papers and books (including some by this author) have been published on its work with all adhering to the standard spelling used by members of the Community. For this reason the Francophone Nebek rather than the English Nabk is used for the nearest town to the site.

8 p. 6o, Kaufhold, Hubert, 'Notizen über das Moseskloster bei Nabk und das Julianskloster bei Qaryatain in Syrien', Oriens Christianus, Band 79 (1995), pp. 48-119. 
ever, although this monastery stands at the eastern extremity of the Qalamoun region of Syria today, we must not let the quirks of twentieth century political geography allow us to view Deir Mar Musa in isolation. To the west of the modern border over in Lebanon there is copious evidence of caves being used for Christian religious purposes. There have also been references to early Christian usage of caves along much of the contemporary Syrian-Lebanese border, but even before the war it was difficult for anybody who was not native to the region to undertake fieldwork along the border zone due to the presence of security forces. ${ }^{9}$

When we view Deir Mar Musa in conjunction with the Lebanese evidence, we can see that cave monasticism was just as well established in Syria (in the sense of the Romano-Byzantine definition of the region) as it was in other regions more famous for cave asceticism such as Palestine and Cappadocia in Asia Minor. In this case the centre for these forms of monastic activity was Wadi Qadisha (Holy Valley) in northern Lebanon. Wadi Qadisha possesses many monasteries, cave churches and hermitages built entirely or partially incorporated into the caves and overhangs of this deep limestone valley. Thus far most of the academic work on the region has concentrated on recording epigraphy ${ }^{10}$ or cataloguing frescoes ${ }^{11}$ and so there is little archaeological data available. What little excavation that has been undertaken so far has largely been carried out by amateur speleologists rather than trained archaeologists, although there has been some attempt to publish these findings in an academic format. ${ }^{12}$

Naturally one must consider the protracted Lebanese Civil War ${ }^{13}$ as one element that has hindered the exploration of this region, and the brief 2006 war with Israel and the overspill of the Syrian Civil War from 2011 onwards are all factors that perhaps explain why Wadi Qadisha does not receive the interna-

As the author observed personally when travelling from Saydnaya to Yabroud late one night along the local roads (rather than the motorway) this area was heavily militarised even before the current war. This was largely because of the Syrian Government attempting to crack down on illicit smuggling activities in the region. Heavy taxes on imported goods made it a very lucrative trade.

Abousamra, Gaby, 'Syriac and Karshuni Inscriptions on Wall Paintings in the Qadisha Valley, Lebanon', Journal of Eastern Mediterranean Archaeology and Heritage Studies 4:2-3 (2016), pp. 148-193.

Hajj, May, 'Wall Paintings in the Qadisha Valley, Lebanon: Various Styles and Dates', Journal of Eastern Mediterranean Archaeology and Heritage Studies 4:2-3 (2016), pp. 194-208. See for example Baroudi, Fadi (ed.), Momies du Liban. Rapport préliminaire sur la découverte archéologique de 'Āṣi-l-Hadaț, Édifra; Beirut, 1994. 
tional recognition of a comparable monastic centre such as Cappadocia. Certainly the region is viewed as the spiritual heart of the nation by Lebanese Christians ${ }^{14}$ but has received relatively limited attention from outsiders. One element of this could be that, despite the undoubted beauty of the valley and its monuments, caves are utilised as part of some of these buildings but we rarely encounter fully excavated monuments as at Cappadocia. Instead conventional stone buildings are grafted on to rocky overhangs or extend outwards from caves in hybrid constructions. ${ }^{15}$ This pattern can also be observed to some extent in the eastern extremity of this region where Deir Mar Musa is built on a rocky outcrop with the stores, cisterns and library of the central building being fashioned from the bedrock. Elsewhere in the monastery the remnants of walls across caves, notably at the cave known as Dayr al-Hayek (the monastery of the weaver) for the loom that was discovered there, show a similar tendency to modify natural caves with conventional building techniques. ${ }^{16}$

In other areas of the country, as mentioned above, Syria is mostly unsuited to this type of monasticism with the east of the country dominated by steppe and desert and the other regions of the west being home to many hundreds of late antique churches and monasteries built of limestone or basalt depending on the local geological conditions. Because there has been no systematic study thus far, we cannot say with any certainty what kind of relationship the monks of sites like Deir Mar Musa had with their co-religionists in Palestine but evidence from graffiti, hagiography and archaeological finds all suggest that foundations such as Deir Mar Musa were waystations for pilgrims travelling overland to the Holy Land and therefore it is logical to assume that there were close connections between the two regions. There is also abundant evidence that the mountains of the Lebanon and anti-Lebanon ranges were criss-crossed with paths and culturally and linguistically homogenous with territories now lying on the Syrian side of the border. Therefore we can see that these links

14 Although today there are some tensions as the Maronite Church claims most of the sites as their own creating hostility with other denominations - in particular the Chalcedonian Rum (Roman) or Arab Orthodox Church, who also lay claim to many of the churches. Both admit to the presence of the Syrian Orthodox in the region in the past, but as their numbers are now neglible in most of Lebanon they are largely excluded from this contemporary struggle for dominance. For some of this see Chaaya, Anis, 'The Qadisha Valley, Lebanon', Journal of Eastern Mediterranean Archaeology and Heritage Studies 4:2-3 (2016), pp. 127-147.

15 This is also the case in Kvemo Kartli and Imereti in Georgia as we shall see later in this chapter.

16 See http://architectureandasceticism.exeter.ac.uk/items/show/33o for images of this cave. 
ran both north-south and east-west from the borderlands that stood between the Syrian Desert and the mountains as far west as the Mediterranean. This leads us on to the next consideration, namely whether foundations of a comparable type in size, age and organisation occurred in Kartli and Kakheti and whether similar lines of communication can be discerned with the Georgian monuments.

\section{Kakheti: The Case of Davit Gareja}

As mentioned elsewhere in this book, Davit Gareja is the name given to a sprawling complex of rock-cut monasteries and hermitages in the south of Kakheti in a region that now, somewhat problematically, straddles the contemporary border between Georgia and Azerbaijan (Fig. 26). Although the lavra of Davit Gareja, the monument at the heart of this monastic network, slightly follows the model of Deir Mar Musa by being partially built in conventional manner and partially rock-hewn, it is largely closer to the Cappadocian type of monastic architecture in that apart from the defensive walls and the structures incorporated in those walls, the majority of the lavra buildings are hewn from the limestone in a manner more reminiscent of Cappadocia than the hybrid constructions of Syria. However, away from the lavra other parts of the wider complex such as the monastery known as Udabno (desert) are completely excavated from the rock.

In fact this trogloditic architecture is a feature of the wider Georgian archaeological context with the earliest large settlement of this kind being Uplistsikhe in Shida Kartli that dates back to the second to first millennium BCE. Evidence from Kakheti, both Kvemo Kartli and Shida Kartli, and Imereti ${ }^{17}$ suggests that all these regions experienced some expansion of cave-dwelling in late antiquity at the time Christianity was becoming established in Georgia. ${ }^{18}$ However, returning to the specific case of Davit Gareja, we can see that here in the vast majority of cases, not only were caves modified as dwelling places but the churches themselves, in addition to service buildings such as refectories, were all excavated entirely from the rock, rather than merely using a cave as a starting point to graft on an additional structure.

Therefore it appears at first sight that rather than looking southwards to the monasteries of Palestine and Greater Syria, in architectural terms the churches,

17 Geographically west Georgia, but culturally and politically dominated by the east.

18 Pers. comm. Nodar Bakhtadze. 


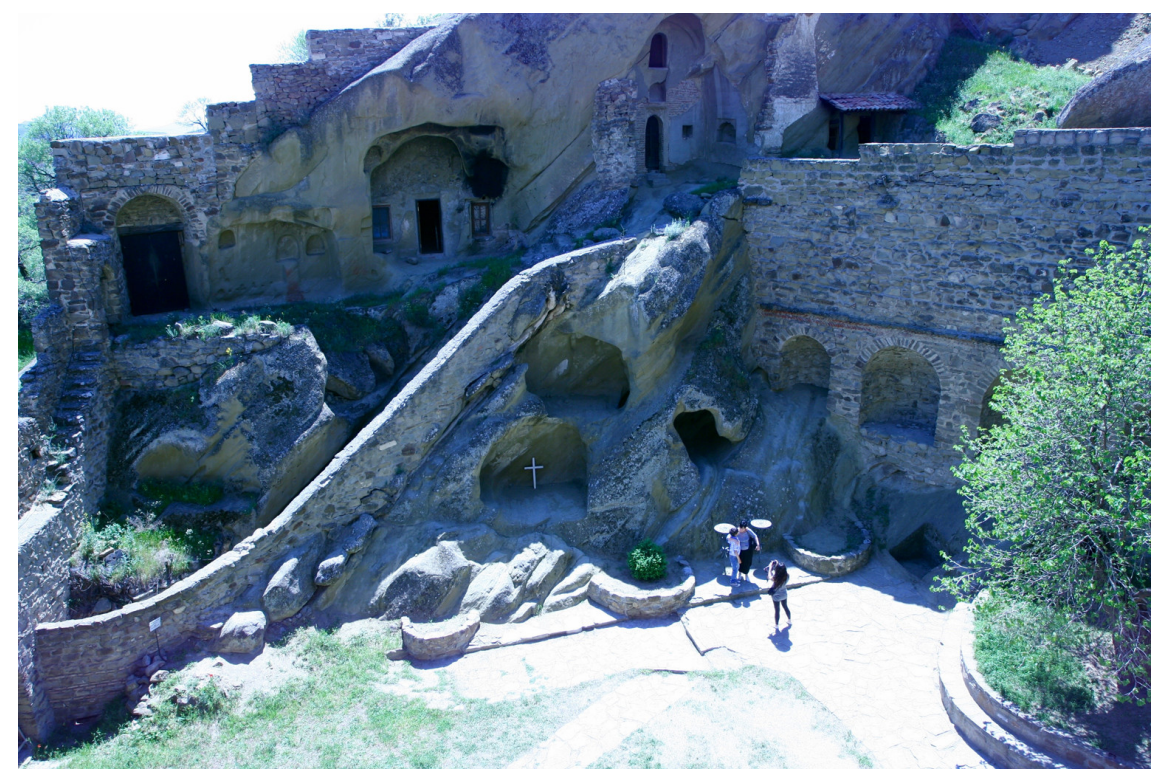

FIGURE 26 The lavra at Davit Gareja

monasteries and hermitages of Davit Gareja seem to follow the model of Cappadocia where whole complexes were constructed by hollowing out the rock rather than augmenting existing caves and overhangs with conventionallyconstructed stone walls. One factor that could be considered is that the influences on the monasteries at Davit Gareja could have evolved and changed over time. It is believed that the first monastic occupation of the region dates to the sixth century, the time that the (As)Syrian Fathers are accepted as coming to Kartli. However, as with many other monuments of this size and complexity, there has been only limited excavation at a selection of test sites ${ }^{19}$ and there are many areas that remain unexplored. In addition continuous occupation from the sixth until the nineteenth century and the rehabilitation of the complex for monastic use since 1991 has made it more difficult to reconstruct the historical chronology of the site and, thus far, typological comparisons between the church architecture and iconographic and stylistic studies of the extant frescoes have dominated the study of Davit Gareja.

19 Pers. comm. Nodar Bakhtadze and Zaza Skhirtladze. Thanks are due to both for kindly discussing their research with me and sharing their ideas about the state of research at Davit Gareja. 
Naturally it would be extremely helpful if in the future studies are published comparing the frescoes of Cappadocia with those of this monument and also an architectural comparison of the corresponding churches, but bearing in mind the cost and difficulties of obtaining excavation permits, even a survey that took account of the wider disposition of the monastic accommodation and compared the location and size of the church in relation to the refectory and other communal areas; how these monastic centres were located with reference to the cells; the number, size and disposition of the cells and variant organisational buildings within one wider grouping of monasteries would all be useful studies that would help us clarify some of the questions raised above.

At the time of writing it does seem that there is strong evidence to suggest interaction between Cappadocia and Davit Gareja from around the eighth century onwards. This is perhaps not surprising given that by this period Georgia was firmly within the Chalcedonian theological fold and was sending churchmen backwards and forwards across the Byzantine Empire-by the tenth century Iviron Monastery was only the second foundation on Mount Athos when it was consecrated in 976. In addition it is from the eighth century onwards that Vakhtang Djobadze found clear evidence of a strong Georgian presence in the monasteries around Semandağ and the Black Mountain in the vicinity of Antioch. ${ }^{20}$ Both these factors attest to a growing relationship with the Byzantine Empire and with lands accessed via Asia Minor from the eighth century onwards, but before this date the evidence of the material culture from Kartli and Kakheti suggests that ties were closer with lands to the east and south, namely the Persian Empire and Mesopotamia, than they were with the territories to the west.

However it must be acknowledged that events are much less clear in the earliest period of occupation at Davit Gareja. As mentioned in chapter three, a find from a grave at Berebis Seri ('the hill of monks') of a silver amulet of Symeon Stylites is, in the opinion of this author at least, likely to have been a sixth or seventh century object that ended up being buried in the grave of a ninth or tenth century monk. ${ }^{21}$ It could be simply that a Georgian monk from the region of Symeon the Younger's monastery near Antioch wore the amulet when he returned home to his native land or it could be an object considered

20 Djobadze, Wachtang Z., Materials for the study of Georgian monasteries in the Western environs of Antioch on the Orontes, Corpus Scriptorum Christianorum Orientalium 372, Subsidia 48, Louvain, 1976, Djobadze, Wachtang, Archaeological Investigations in the Region West of Antioch On-The-Orontes, Franz Steiner Verlag Wiesbaden Gmbh; Stuttgart, 1986. 
ancient at the time it was put in the grave and point to a less linear relationship with one or both of the Stylite shrines. What remains unknown is whether or not such objects were trafficked between Syria and Davit Gareja before the well-attested link with Antioch from the eighth century onwards and, even if we are unable to find evidence of an earlier link, why is it that evidence of Antiochene-Kartvelian relations are clear from the eighth century onwards but so exceptionally sparse before that period? These questions must remain unanswered at present, but offer intriguing possibilities for future research. However Davit Gareja is only one of the many early Christian cave sites known in Georgia today. It remains the most famous and, to date, best-explored complex of this era, which means that our knowledge of other sites is even more speculative as will be seen below.

\section{The Caves of Kartli: Another Paradigm of Cave Monasticism?}

Across the regions of Kvemo (lower) and Shida (inner) Kartli a number of caves have been surveyed and recorded in the search for evidence of human occupation. Kvemo Kartli is most famous in world archaeology for being the place where the first hominid remains yet found outside Africa were discovered at Dmanisi from 1991 onwards. It has many caves located along a number of river valleys and these have been occupied at a variety of different periods. From the 1980s onwards they were surveyed by a team led by Nodar Bakhtadze, and he published a number of sites in a preliminary volume in $1991 .{ }^{22}$ This book has been followed by articles on individual sites $^{23}$ and a large survey volume on the evolution and architecture of Georgian rock-cut monuments ${ }^{24}$ but has not yet been followed by the intended second book on Kvemo Kartli. However, the process of surveying, and in some instances excavating test trenches, has continued up into Shida Kartli and over to Imereti in the west. Imereti must be viewed as a liminal territory in that although it lies geographically in the west of modern Georgia and therefore should fall under the sphere of influence of Egrisi rather than Kartli, the archaeological and historical evidence suggests that culturally and politically Imereti was allied far more closely with the east

22 Bakhtadze, Nodar, Kvemo kartlis kldis dzeglebi, Sakartvelo; Tbilisi, 1991.

23 See for example Bakhtadze, Nodar, 'Manglisis midamoebshi akhlad gamovlenili samonastro ansambli', Khelovnebatmtsodneoba 5 (2003), pp. $5^{-15}$.

24 Bakhtadze, Nodar, Kldis khurotmodzghvrebis genezisi da ganvitarebis gzebi sakartveloshi, National Museum of Georgia; Tbilisi, 2007. 
than the west and therefore in terms of material culture is more akin to Kartli and Kakheti than it is to neighbouring regions in Egrisi/Lazica. ${ }^{25}$

Certainly the preliminary evidence from cave surveys suggests that the ascetic practices followed in this region were more extreme than elsewhere in the Caucasus and this kind of radical mortification in late antiquity is often perceived as a symptom of Syrian monasticism. Theodoret's testimony relating to 'spiritual athletes' mortifying their flesh with endurance practices such as living in open pens like animals, extreme fasting or other forms of bodily mortification ${ }^{26}$ mean that similar dedication to punishing the body in order to attain spiritual perfection is often linked to Syrian monasticism. The ongoing surveys in Imereti have yet to be published, but evidence so far suggests that in at least one instance a solitary monk lived in a well-like aperture in a cave from which he could not ascend without assistance and where he would have been at the mercy of his brethren for water and nourishment. ${ }^{27}$

This kind of practice is not referred to in early Georgian monastic literature and, as observed in chapter four, at least one current of extreme Syrian ascetic practice - that of Stylitism - was mediated by the pragmatic Kartvelians to a more manageable form of asceticism by substituting a column for a 'tower house' or, in the case of Katskhi's sveti, a conventional monastic cell atop a pinnacle of rock in a manner that is closer to Meteora in Greece than it is to the columns of Qal'at Sem'an and Semandağ. Bearing this apparent pragmatism in mind, the possibility of extreme ascetic practices in the caves of Imereti does require further future investigation and could well hint at links with an older current of Syrian extreme mortification that may have entered Kartvelian territory with stories of stylitism; it must be remembered that two of the Georgian sites linked to Georgian stylite practices (as opposed to the original Syrian version) are at Ubisi and Katskhi in Imereti, with other examples found further east and west at Martqopi, Kvemo Kartli and Martvili, Samegrelo. Certainly this Kartvelian 'stylitism' seems to have been more a product of central and western Georgia than a purely eastern phenomeon. Given the later dates of these Kartvelian 'stylites' and the fact that they are first recorded from approximately

\footnotetext{
25 This appears to have been a phenomenon over various different periods of Georgian history - my thanks to Nodar Bakhtadze who discussed this situation as it related to the late antique and medieval periods and Mikheil Abramishvili who alerted me to the fact that the same pattern is clear in the archaeological record of the Georgian Bronze Age.

26 Theodoret of Cyrrhus, Trans. Price, R.M., A History of the Monks of Syria, Cistercian Publications; Kalamazoo, 1985 .

27 Pers. comm. Nodar Bakhtadze.
} 
the eighth or ninth century onwards, ${ }^{28}$ again it seems likely that this influence came about in the aftermath of Georgia entering the Chalcedonian doctrinal fold after the seventh century; it does not appear that this was a result of earlier contact directly with sixth century Syrian monasticism.

On the other hand the preliminary findings of extreme ascetic practices in Imereti and the fact that the rock-cut churches and cells of Kvemo Kartli and Imereti follow the Lebanese monuments by grafting conventional stone walls to overhangs and caves, does point clearly to potential traffic between the two regions. This needs to be explored carefully in the future, because if this does yield evidence of earlier interaction between Kartli and Syria it will be in intriguing opposition to the evidence found at conventionally built churches and monasteries across Kartli and Kakheti.

\section{Christianity and the Mountain Cultures of Georgia}

At this point it is necessary to move on to the other unknown factor that has not been clearly resolved by this study; the relationship between Georgian mountain cultures and early Christian belief. Are there traces of early Christian rites still extant in the traditional festivals of Georgian mountaineers or are their antecedents wholly without a Christian element?

Anybody studying the medieval Christian culture of Georgia will be told of the belief that Svaneti in the western Greater Caucasus has long played a role as the stronghold used to guard the Georgian national treasury. This is because Georgia's pivotal geographical location at a global crossroads has had both advantages and disadvantages, with many Georgians believing the latter outweigh the former. The strategic significance of Georgia, coupled with its fertile agricultural lands, mineral resources and access to the Black Sea have made it an irresistable prize for regional powers for many millennia and most Georgians would concede that this struggle continues today as the country steers a course between their former overlords, the Russians and the blandishments offered by the likes of NATO and the EU, with the USA first among these new courtiers. In the past these territorial ambitions were most likely to be played out on the battlefield and, as Georgians are the first to admit, this means that the country has been invaded by a plethora of powers over the centuries. Nat-

28 See Gagoshidze, Giorgi, 'Katskhis Sveti', Akademia, 1 (2010), pp. 55-68 (English translation: Gagoshidze, Giorgi, translated from the Georgian by Loosley, Emma, 'Katskhi Pillar', Collectanea Christiana Orientalia 12 (2015), pp. 208-306). 
urally to survive, and in many ways even to thrive, in such an unstable region has meant the formulation of certain strategies. Some of these appear to have involved appeasement and a certain degree of assimilation - a clear example of this is the great number of loan words from Persian, Turkish and Arabic in contemporary Georgian, as well as the presumably later linguistic stratum provided by words of Russian origin. Another factor has been contingency planning to protect certain objects and texts that were considered particularly significant and this is where Svaneti entered the equation.

Svaneti is believed to have been evangelised from around the eighth or ninth centuries $\mathrm{CE}$ with the earliest churches being dated to the ninth or tenth centuries. This means that it began to be part of Christian culture in the period several centuries after the country embraced Byzantine doctrine and at a time when there is clear evidence of interaction with the monasteries in the hinterland of Antioch. To this day the region possesses more frescoes, but also more icons and liturgical metalwork and other ecclesiastical accoutrements such as vestments, than any other region of Georgia; indeed it could be argued that this is possibly the most significant collection of medieval ecclesiastical artefacts gathered in one region anywhere in the world. ${ }^{29}$ However not even the museum in Mestia holds all of the artefacts in Svaneti as those of the Ushguli Community remain in a traditional 'treasure house' in a medieval tower in the village of Chazhashi.

Because of this very visible role in the safeguarding of medieval Christian material culture, when traditional religious practices and the role of the mountain peoples are discussed in relation to the growth and spread of Christianity, Svaneti is the first place considered. Because the eastern mountaineers, the Khevsurs, the Pshavs and the Tushes, do not have overtly Christian religious belief systems ${ }^{30}$ they have often been excluded from this discourse and yet

29 The majority of these artefacts were consolidated in one secure, climate-controlled location with the building of the Mestia Museum, part of the National Museum of Georgia, which opened in 2013. The collection is superbly displayed and is well worth the effort of travelling to Mestia, even without the added incentive of visiting the fabled towers of Svaneti.

30 With regards to the Khevsurs, Kiknadze in Kiknadze, Zurab, Kartuli mitologia, I. Jvari da saqmo, Gelati Academy of Sciences; Kutaisi, 1996, posits that the Khevsurs were Christians who then lost touch with the lowlands and a layer of pagan belief overlays a Christian substrata. This is discussed at length by Tuite in a review article, Tuite, Kevin, 'Highland Georgian Paganism: Archaism or Innovation?', Annual of the Society for the Study of the Caucasus 6/7 (1996), pp. 79-91 where he argues for a different chronology and, at the time of writing, this debate is still ongoing. 
it seems that they too could greatly aid our understanding of the early evolution of Christianity in Kartvelian lands. It is clear that these communities were not as cut off from the rest of the world as has been assumed in the past; they regularly traded with other groups and had frequent contacts with each other (in the case of the Khevsurs, Pshavs and Tushes) and with other mountaineers from the northern slopes of the Caucasus. This meant that, whilst they all maintained their own distinct religious identities with variant ritual practices, these identities were not fixed and inflexible. Rather they gradually adapted and assimilated some ideas from neighbouring regions, in some cases even going so far as to share some of the most significant shrines, and changed over time in reaction to evolving historical circumstances.

Therefore the old categorisation of the lowlanders as being Christian, with the eastern Mountaineers being pagan and the Svans falling somewhere along the spectrum between the two has been superceded by an understanding of the situation whereby it is understood that folk beliefs are still alive and well in the lowlands, just as there are elements of Christianity clearly identifiable in some elements of Khevsur religious belief. Over seventy years of Communism caused a certain degree of disruption to aspects of Georgian religious life, but what is clear is that the mountainous regions often maintained a degree of autonomy that was denied the lowlanders and that therefore this is a good place to start if we want to explore more ancient currents of faith practices. Of course there are factors that have disrupted these mountain cultures as well, most significantly the wholesale deportation of the Khevsurs to the lowlands by the Soviet forces in the 1950s, but despite this many of the traditional faithleaders and shrines survived this great setback and the faith was by no means completely eradicated. Now the challenge is to preserve these ancient beliefs in the face of an increasingly dominant and muscular Georgian Orthodox Church.

At this point it becomes necessary to go back and look at the religious picture of Kartli and Kakheti at the time that Christianity arrived in order to understand the pre-Christian currents that permeated Kartvelian Christianity and how this situation may have influenced highland beliefs.

\section{The Currents That Preceeded Christianity and Possible Modes of Christian Dissemination}

As with so many other questions raised in this work, when we explore the pre-Christian religious landscape of Georgia we are left with certain gaps in the archaeological record that, it is to be hoped, may be clarified by future researchers as more material is excavated and if new discoveries are made from 
advanced textual analysis. What we do know is that the Persian domination of the country meant that Zoroastrianism was present in the Persian élite but the Kartvelian nobles worshipped a pantheon headed by the God Armazi. It has been posited that this Armazian belief system was heavily indebted to Zoroastrianism, but there is still some debate as to how pre-Christian Kartvelian religion was enacted. Certainly the Armazian cult was dominant around the wider Mtskheta region in the first centuries CE and on into late antiquity. This status quo is alluded to in the text of the Kartlis Tskhovreba where the writer describes the idol of Armazi that St. Nino showed to be powerless. ${ }^{31}$ Whilst the Armazian and Zoroastrian faiths are widely accepted as being widespread in the centuries preceding the Christian conversion of Kartli, it is also accepted that there were other faiths present including a Jewish community in Mtskheta and Urbnisi and the pagan beliefs of villagers and mountaineers. More recently Mgaloblishvili and Rapp have added an extra element to the mix with their investigations into the presence of Manichaeism in Kartli. ${ }^{32}$ However, one significant area that is not yet fully understood is how the process of conversion unfolded across the country as it spread outwards from Mtskheta. The texts are clear that the conversion of Kartli followed a top-down model with St. Nino evangelising King Mirian and Queen Nana, who then enjoined their court to follow and therefore Christianity permeated downwards from the upper classes to the lowest levels of society. However because of this model, as mentioned elsewhere, the archaeological study of early Christianity in Kartli has thus far privileged the region around Mtskheta and also Urbnisi—both locations linked with St. Nino's vita and known to have had early Jewish communities. There has not been the same attention paid to Kakheti, where St. Nino is recorded as having lived out the later years of her life before dying at Bodbe. Without excavation and relying on the evidence of standing architecture, the spread of Christianity was believed to have radiated outwards from the centre at Mtskheta with small churches being built in the further provinces as Christianity more gradually began to permeate outwards.

As with so many theories based on survey alone, this theory has been increasingly discredited in the last few years. Excavations at Armazistsikhe and Armaziskhevi near Mtskheta and at Dedoplis Gora and Dedoplis Mindori near

31 pp. 50-51, Metreveli, Roin \& Jones, Stephen (eds.), Kartlis Tskhovreba, Georgian National Academy of Sciences, Commission For The Study of Georgian Historical Sources, Gamomtsemloba Artanuji; Tbilisi, 2014.

32 Mgaloblishvili, Tamila \& Rapp, Stephen H. Jr, 'Manichaeism in Late Antique Georgia?', in Van den Berg, Jacob Albert (ed.), In Search of Truth: Manichaica, Augustiniana and Varia Gnostica, Brill; Leiden and Boston, 2011, pp. 263-29o. 
Gori, and significantly not far from Urbnisi, suggest that Christianity was actually slow to gain a toehold in these sites associated with the ruling Kartvelian classes. They appear to have been close in cultural terms to their Persian overlords and therefore slower to relinquish their Persian-influenced religious practices. The archaeological evidence instead offers a picture where near the centre of power pre-Christian beliefs took longer to die out, ${ }^{33}$ whilst out in the provinces regional notables appear to have adopted the new faith faster than those with closer ties to the Sassanian court. The evidence for this comes largely from the Kvareli region of Kakheti thus far, ${ }^{34}$ but it is hoped that a clearer picture will emerge as more regional late antique sites are excavated rather than merely surveyed. However, the location of our regional information in Kakheti is significant; not only is it in the north of the region where St. Nino is reputed to have died, but it is also an area associated with five of the thirteen fathers. In addition it is geographically the closest Kartvelian territory to Persia and, naturally, this makes it the most removed from the influence of Graeco-Roman culture.

Therefore in Kakheti we have a region that has long been known for its prosperity due to the fertile soil, well-watered river valley and pleasant microclimate of the Alazani valley as well as being a notable crossroads with trade raditating in all four cardinal points. On the other hand this enviable location and the reasons that it became prosperous from trade links also often led to the region suffering punitive raids from the north, east and south. Despite this, the evidence from recent excavations at Chabukauri and Dolochopi on the territory of Nekresi show that large Christian basilicas were being built from the fourth century onwards. ${ }^{35}$ This was happening far from any major centres of power- the towns in question were hubs for the northern Alazani Valley but do not appear to have had a greater geographical significance. The excavation of a pagan temple in the territory of Nekresi that appears to have died out in the

33 Thanks are due to Dr Iulon Gagoshidze who has excavated at the sites mentioned above for his information on the religious practices of these settlements in late antiquity and his observation that Christianity seems to have taken root in the provinces first. Work at a number of these locations is ongoing, has not been published or is only available in Georgian language archaeological journals. The exception is the Dedoplis Gora project that has been fully published in an English language monograph: Furtwängler, A., Gagoshidze, I., Löhr, H. \& Ludwig, N. (eds.), Iberia and Rome: The Excavations of the Palace at Dedoplis Gora and the Roman Influence in the Caucasian Kingdom of Iberia, Beier \& Beran; Langenweißbach, 2008.

34 This is the subject of a forthcoming collaboration by the author and Nodar Bakhtadze.

35 See Chapter 2. 
third century $\mathrm{CE}^{36}$ would also support this narrative of the older faith(s) declining in this area by the fourth century and thereafter the swift Christianisation of the wider region.

Taking this into account, if this pattern is supported by excavations in other regions we have a situation where Zoroastrian and other dualist religions (the Armazian tradition, Manichaeism) were superseded by Christianity in a process that travelled at different rates but that appears to have been largely complete in the Kartvelian lowlands by the sixth century CE. What we also know is that the highlands had regular contact through trade and, in the case of the Tushes, a pattern of seasonal migration that would have brought them into proximity with lowland religious practices. This raises the question as to how far their beliefs absorbed elements of these religions and whether or not this can help us discern any early Christian practices left as vestiges of traditional worship.

\section{Some Thoughts on Christian Remnants in Vernacular Religion}

As discussed in chapter six, there is an intriguing hint of a link between Mesopotamian Assyrian liturgical tradition and Kartli in the possible survival of a variant of the liturgy of the bema in vernacular worship. This possibility is suggested as a use of the nave platforms that appear to have been widespread in early and medieval Kartvelian Christianity, but that now only remain in a handful of sites such as Anchiskhati basilica in Tbilisi and Jvari outside Mtskheta. There is also the unresolved issue of how these platforms and their pre-altar crosses were transmitted to the western regions and how the practice of large pre-altar crosses became ubiquitous in Svaneti. We then have the question of whether the syncretistic practices recorded with Svan pre-altar crosses as late as the $198 \mathrm{os}^{37}$ fit into this overall pattern. Even at this stage, whilst acknowledging that the subject needs much more attention, there is a possibility that this link is another 'false friend' in our hunt for links between Kartli and Syria.

This is because although the largest number of nave-platforms (bemata) still extant are located in approximately fifty churches on the Limestone Massif of

36 Simonia, Irakli, Ruggles, Clive \& Bakhtadze, Nodar, 'An Astronomical Investigation of the Seventeen Hundred Year Old Nekresi Fire Temple in the Eastern Part of Georgia', Journal of Astronomical History and Heritage 12:3 (2009), pp. 235-239.

37 My thanks to Kevin Tuite to confirming the continuation of these rituals and to explaining how they have become endangered with the post 1991 growth of the Georgian Orthodox Church. 
northwest Syria, they appear to have fallen out of use from around the seventh century onwards. However, the liturgical evidence suggests that this bema liturgy remained a central element of the Church of the East and the Syrian Orthodox Maphrianate of Takrit well into the medieval era. ${ }^{38}$ This region was of course part of Assyria (Mesopotamia) and once again we are led in the direction of an Assyrian influence, but without further research cannot definitively rule out that this particular liturgical practice may have entered Kartli from Syria.

The other possible remnant of an earlier tradition that appears to have survived in vernacular religion is the festal calendar. Naturally this should not come as a great surprise given how many 'Christian' festivals appropriated earlier feast days and assimilated them into the new faith. As discussed briefly in chapter six, the distinctive mode of dividing periods of time into Pentecostads is an element of Armenian and Assyrian Christian calendars that appears to have entered Christianity via an older tradition that has been traced back at least as far as Second Temple Judaism. ${ }^{39}$ This ancient calendar has survived in Christian traditions of different doctrinal schools as we find the Assyrians (non-Ephesian) and the Armenians (non-Chalcedonian) both honouring ancient festivals of obscure origin on this calendar and yet the West Syrian nonChalcedonian Syrian Orthodox Church does not have an analogous rite. On the other hand the Christianised traditional rite of Atenagenob ${ }^{40}$ derives from the Vardoba-Atenagenoba rite that is still practiced by both the Armenians and the Assyrians.

The Armenian calendar equates Vartavar with the Christian Feast of the Transfiguration, even though the Armenian Church acknowledges that this timing is appropriated from an earlier, pre-Christian feast:

In pagan times, Vartavar was the "festival of roses" - vart is the name of the flower in Armenian (and Persian) - associated with the summer activities of the agricultural cycle. Draft animals would have their foreheads adorned with roses as they went about their work in the fields,

38 See Loosley, Emma, The Architecture and Liturgy of the Bema in Fourth to Sixth-Century Syrian Churches, USE K, Patrimoine Syriaque vol. 2; Kaslik, Lebanon, 2003 (re-issued in a second edition by Brill, 2012).

39 Lourié, Basil, 'The Liturgical Cycle in 3 Maccabees and the 2 Enoch Calendar', Études Bibliques (2016), forthcoming.

40 Mgaloblishvili, Tamila, 'The most Ancient Feast of Vardoba-Athenagenoba', in Stone, Michael E., Ervine, Roberta R. \& Stone, Nira (eds.), The Armenians in Jerusalem and the Holy Land, Peeters; Leuven, 2002, pp. 157-165. 
and athletic competitions of strength, speed and skill would be held to honor the month of Navasart, ringing in the Armenian New Year. Vartavar was also steeped in the familiar pagan cult of love and death: it was the major midsummer festival of the water-born goddess of love-Aphrodite in Greece, Astghik in Armenia — and her handsome-but-doomed-consort ...$^{41}$

The quotation above is taken from a guide to the Festival of the Transfiguration written for members of the Armenian Church and it goes on to point out that the priest sprinkling water over the congregation (and the laity throwing water over each other in fun) is a remnant of this earlier tradition. In fact such a tradition also continues elsewhere-the Syrian Orthodox (West Syrian) Church follows this practice but in their case the water throwing occurs on Pentecost, not on the Feast of the Transfiguration. ${ }^{42}$ On the other hand the Assyrian Church celebrates Nusardel or 'Assyrian Water Day' at approximately the same point in the Church calendar as Vartavar. Whilst we can posit a link between all these practices, the same guide to Armenian Transfiguration beliefs appositely states that:

The regional character of the older observance can be seen in the fact that the Georgian Orthodox Church once celebrated a feast known as Vardoba-Atenagenoba around the same time of year-although the Georgian event had no connection to the gospel episode of the Transfiguration. ${ }^{43}$

Therefore what this suggests is that whereas in Armenia this earlier pagan festival was eventually conflated with a Christian festival and survived in that manner, and something similar appears to have occurred in the Assyrian tradition where Nusardel is part of their liturgical year, in Georgia there was no linking of Vardoba with a major Christian feast. Whereas in the Kartvelian context this observance seems to have fallen out out of mainstream Christian practices, it survived in the grey area between Christianity and vernacular belief as the Atenagenoba festival. Therefore it now forms part of the Georgian tradition of

\footnotetext{
41 Antreassian, Elise, Findikyan, Daniel \& Zakian, Christopher, Living the Gospel of Christ: Transfiguration, Diocese of the Armenian Church of America Eastern; New York, 2013.

42 The author knows this from having been soaked by children and teenagers on overhead balconies in the Hay al-Suryan quarter of Aleppo after the Pentecost service.

43 Antreassian, Elise, Findikyan, Daniel \& Zakian, Christopher, Living the Gospel of Christ: Transfiguration, Diocese of the Armenian Church of America Eastern; New York, 2013.
} 
regional festivals that may or may not have ostensibly Christian origins and which occur throughout the calendar year.

These observations are of course still very much preliminary thoughts on these issues and it is to be hoped that future research will clarify these questions in the future. It is widely acknowledged that research often raises as many questions as it answers and, within the parameters of the current research, these are the intriguing 'loose ends' that need to be examined further. 